\title{
CROP INSURANCE - RISKS AND MODELS OF INSURANCE
}

\author{
Vladimir Čolović, ${ }^{1}$ Nataša Mrvić Petrović ${ }^{2}$
}

\begin{abstract}
Summary
The issue of crop protection is very important because of a variety of risks that could cause difficult consequences. One type of risk protection is insurance. The author in the paper states various models of insurance in some EU countries and the systems of subsidizing of insurance premiums by state. The author also gives a picture of crop insurance in the U.S., noting that in this country pays great attention to this matter. As for crop insurance in Serbia, it is not at a high level. The main problem with crop insurance is not only the risks but also the way of protection through insurance. The basic question that arises not only in the EU is the question is who will insure and protect crops. There are three possibilities: insurance companies under state control, insurance companies that are public-private partnerships or private insurance companies on a purely commercial basis.
\end{abstract}

Key words: insurance, agriculture, crops, premium, risk.

JEL: $K 12, Q 10$

\section{Introduction}

Agricultural insurance is a type of insurance that carries various risks and many of them, if actualized, result in serious consequences. For this reason, agricultural insurance is a challenge for insurance companies (insurers), both state-owned and privately-owned insurers. Also, at the same time, it is a challenge for the government whose interest is to protect this branch of economy that is due to "unforeseeable" and serious risks subject to large losses. Crop insurance in most cases also includes fruits, is one of the forms of this type of insurance linked to various risks. But, generally, insurance is not the only form of crop and agriculture protection. There are other protection models as well. However, the bringing of one agriculture protection plan through insurance, with the expectancy of various models, is the safest and overall protection.

1 Prof. Vladimir Čolović, Ph.D, Full Professor, Principal Research Fellow, Institute of Comparative Law, Terazije 41, 11000 Belgrade, Serbia, Phone: +381 11323 32 13, E-mail: vlad966@hotmail.com

2 Prof. Nataša Mrvić Petrović, Ph.D, Full Professor, Principal Research Fellow, Institute of Comparative Law, Terazije 41, 11000 Belgrade, Serbia, Phone: +381 11323 32 13, E-mail: petroviczdravko@ikomline.net

EP 2014 (61) 3 (561-573) 
The question is as to what the starting point is for the rural producer to bring his/her own decision concerning crop insurance. Firstly, the minimum amount of money that would pay costs and ensure profit. Secondly, the main crop risks. After response to those two issues, a decision can be brought concerning a specific insurance product. Practically, a larger insurance premium would cover more risks. But, it is necessary to opt for optimum insurance (Bastian, 1999).

In order to reach optimum insurance, it is necessary to fulfil several factors and this affects the volume of the amount for which one rural producer is prepared to give in part or fully to alleviate the effects leading to agricultural losses. Those are: 1. Evaluation of the size of potential loss in respect of the rural producer's profit; 2. Evaluation of loss frequency: 3. Reality of expected real loss; 4. Evaluation of the cost of risk alleviation; 5. Determination of measures that management risk strategy provides protection from losses; 6 . How much is an agricultural husbandry prepared to pay in order to adopt a specific strategy for risk management (Smith, Watts, 2009).

In order to discuss the risks related to crop insurance, it would be firstly necessary to pay attention to the concept of risk and its particular types.

\section{On risk generally}

Almost any insurance is associated to risk. Risk is a state of uncertainty. It is a future, uncertain event the realization of which may cause specific damage or benefit (Šulejić, 2005). Within insurance, risk realization is essential from the aspect of source of the harmful event. When risk is actualized, the insurer is obliged to pay the sum insured. Some authors, regarding risk actualization, make a difference between the economic and public damage. They link public damage to non-life insurance (property, liability insurance, etc.), whereas public damage they link to life insurance (Žarković, 2008). We cannot fully agree with this implication as the difference is very slight and both types of damage could be discussed with different insurance types. Risk could be observed, separately, from the point of view of insured and particularly from the point of view of insurer. If we observe risk from the point of view of insured in the first place, we look at protection from risks. One of those protections is insurance. From the aspect of insurers, we argue insurance activities as well as insurance business alone.

Different types of insurance are associated with various risks. It is not the same risk in motor insurance vehicles for the damage caused to persons who are third parties and in insurance against effects of an accident. The greater the risk, the greater the possibility for the harmful event to occur, ie., the insured case. There is a danger of an increasing number of risks when insurance is compromised, i.e. a possibility of one insurance company to cover specific risks and pay for damages. One of the major problems relating to the existence of risks is its multiplication that is not only an increase the number of risks, but also an increase in the volume of risks (Čolović, 2013).

According to risk importance, there is a difference between compulsory, desirable and available insurance. This categorization is important for the insured as he/she cannot insure 
all risks. Namely, compulsory insurance covers risks that must be insured as well as risks with catastrophic effects that threaten the survival of the insured. Desirable insurance includes risks that could cause serious damage. Available insurance includes those risks that could be "covered", if realized from own resources (Ivanović, 2003).

The next categorization is also important from the insured's aspect, but also from the aspect of the insurer's solvency. It is a chance for insurance so that all risks could be divided into three groups: a) risks that could be fully transferred to the insurer; b) risks that could be partially transferred to the insurer; b) risks that could not be transferred to the insurer at all. All risks that offer economic protection without limitation of the amount of coverage are those that could be fully transferred to the insurer by concluding insurance. The risks that could only be partially transferred to the insurer are those risks that exceed total capacities of insurers and all reinsurance, by the size of potential damage, and one portion of surplus risk remains uncovered. Those are catastrophic risks. The risks that could not be transferred to insurance companies are those risks that are not covered by any insurance type (Milikić, 2005).

\section{Agricultural insurance risks}

The above mentioned risk types may refer, inter alia, to agricultural insurance. It is certain that those risks could also refer to other insurance types. Farmers, very often, face completely new risks. This happens because there are structural changes in agricultural production. Growth in agricultural production inevitably leads to increased mechanization, automatization and intensive production. Any new production processes lead to losses in overall business (Rüegger).

"Ideal risk" is very often mentioned in agricultural insurance. The issue of "ideal risk: must be responded in each particular case. Conditions for "ideal risk" must be fulfilled as much as possible so that we could speak about feasible protection through insurance. Risk, as we have already said, must appear independently of anyone's will and at random. Losses would also be determinable and measurable. "Ideal risk:, from the point of view of the insurance company is a hail The hail could cause serious damage in agricultural production, but, it is actually a small and predictable insurance risk (Rüegger).

The issue of agricultural insurance, otherwise, is very important, but even more so in recent times. Namely, direct insurance premiums in agriculture have significantly risen in the last 15 years. The world level recorded a growth of a total of 8 billion dollars in 2005 to 18,5 billion dollars in premiums in the year 2008. As far as geographical representation is concerned of global premiums in 2008, the main part relates to USA and Canada, whereas European countries account for $17 \%$ of participation in total premium and occupy third position behind Asian countries with $18 \%$ participation. In the structure of premium for 2008 , crop insurance dominates with $90 \%$ of total premiums, whereas all other insurance types in agriculture get premiums of $10 \%$. Insurance products in agriculture existing on the world market could be classified in three main groups based on methods by which the sum insured is paid out: 1) payment of the sum insured is made according to the harmful 
event realized, 2) payment of the sum insured is measured by the index and 3) payment of the sum insured is determined based on realized yields and product prizes (Manić, 2012).

\section{Crop insurance}

Both short-term and long-term forecasts by meteorologists and researchers of climatic changes purport that, apart from global warming, we must expect large quantities of downfalls and violent weather storms that would destroy agricultural cultures to a great extent. Any farmer and the state must have this in mind and specify measures that would protect agricultural cultures from threatening weather conditions and mitigate the loss of crop yields (Marković, Jovanović, 2008).

Fundamentals risks that are protected with crop insurance are hail, fire and thunder. Additional risks are storms, floods and frost. The level of development of crop insurance is measured with the risks covered by insurance, various policy types and with government support (subventions). Later on, we will discuss crop insurance in some European countries. Now, we could say France, Spain, Great Britain, Italy and Germany have the largest area of cultivable soil and the issue of crop insurance in those countries is very essential. It is well known that due to large percentage of funds set aside from the joint budget and the small percentage of agriculture in gross national product, joint agricultural policy carries the epithet of one of the most controversial EU joint policies. Details about risks covered by crop insurance and yields in EU are obtained based on meteorological and agro-meteorological data received after monitoring cereal growth based on vegetation index received from satellite images and EUROSTAT databases (office for EU statistics collecting and publishing statistical data), (Labudović, Todorović, 2011).

Very often within the crop insurance speaks about moral hazard. It is the conduct of the insured with respect to the subject matter of insurance. One of the ways of preventing moral hazard is franchise in insurance. Namely, franchise, i.e., the insured stakes in the premium, and, also, the bonus malus system, aim to reduce the mentioned moral hazard, which refers to the biased risk and adverse selection. As a general rule, the heavier risks are followed with the larger franchises. If the franchise would not have been contracted, i.e., if farmers do not participate partly in the damage, this means they have no incentive to take preventive measures. Larger franchises follow new insurance products for which there is very scarce or there is no experience regarding the damage (Labudović, Todorović, 2011).

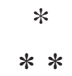

We have already said that insurance is not the only protection in this sphere. There are various models of protection of agricultural cultures, or crops. Some of those models are: funds for compensation for damages resulting from natural disasters, joint insurance funds and insurance. Whether funds for compensation for damages resulting from various weather storms depends mostly upon the government, or its agricultural policy. When there are no market-oriented models for agricultural protection, such as insurance and regional insurance funds, or when it is not enough, those funds help farmers in case of natural catastrophes 
or serious weather storms. In this way, most often are compensated losses of those risks that farmers cannot insure. Joint insurance funds are organized regionally and refer to funds where farmers alone protect themselves from weather storms. The advantage of this regional organization is to avoid this way moral hazard and unnatural selection as the main problems in insurance. As we have already mentioned, moral hazard refers to behaviour by farmers who have insured their crops. They, namely, frequently do not undertake measures for protection of their agricultural cultures so that in case of a harmful event they would lower their losses. Such behaviour has been caused by concluded insurance as, in the case of a harmful event, the insurer would pay for damages. On the other hand, the deficiency of such funds is danger that all or the majority or farmers suffer losses at the same time and this of course could happen if all or the majority of farmers who have set up this fund, have their estates on a specific territory. Also, one should say, that farmers do not always manage to successfully organize such joint insurance funds. Insurance is surely the best instrument for risk management that appears as an important stability factor of any production (Marković, Jovanović, 2008).

\section{Three models of crop insurance}

It is very hard to define models of crop insurance. In order that this insurance type be developed in one country, it is necessary to fulfil certain conditions not only for insurance development in this country, but also the conditions relating to the government strategy in terms of agricultural policy and government investments in agricultural development. Nevertheless, we can define three basic market models through which insurance in agriculture can be accomplished:

1. Systems fully controlled by the government - they are characteristic for very intensive support by the government with the existence of one unified insurance product that is usually commercialized through a state-owned insurance company with a monopolistic position. Those systems are characteristic, expectedly, with a large market penetration due to the obligation and good portfolio diversification, but they means high fiscal expenses, frequent bad service caused by monopolistic position. In this model, the role of the state is the key, i.e., that of the insured where the state has full control;

2. Public - private partnerships - have high penetration and a good diversified portfolio, technical criteria dominate over commercial, there is competition in the provision of services, and the state reinforces system stability. Also, the private sector provides the knowledge and technology, all with reasonable fiscal benefits; and

3. Complete market system - have low to moderate penetration and low level of risk diversification, , commercial criteria dominate over technical, with the realization of competitive prices and without fiscal expenses (Manić, 2012). Practically, all in this model depends on the interests by insurer for dealing with this kind of insurance and this interest, also, depends on definition of agricultural policy in one country.

One should mention the study by the World Bank of 2009 that encompassed an analysis of situations in 65 countries when insurance models in this sphere are concerned. Various approaches have been notices in cases when the government decided to intervene in the 
market insurance segment in agriculture. As regards premium subsidy, this form is the most frequent form of government support to agricultural insurance. The above study shows that even $63 \%$ of countries have opted for this kind of support for crop insurance. When speaking about investments in research work and development of agricultural products, training and collection of information, this study shows that $41 \%$ of countries have opted for this form of support for crop insurance. Development of legal rules associated with agricultural insurance is very essential and by the same study $51 \%$ countries have decided for this form of support for crop protection. Subsidy of administrative costs for issuing insurance policies in agriculture is the least used form of support and according to the same study only $16 \%$ countries have opted for this form of support for crop protection (Manić, 2012). This study, also, refers to other insurance types within agricultural insurance. We must say that premium subsidy by the government, without development of other models when state intervention in this insurance type is concerned, cannot bring long-term results. If we compare the percentage of countries that opt for subsidy with the percentage of countries that have decided for development of legal rules in this sphere, we shall see that decisions concerning premium subsidy are brought pursuant to the current need and circumstances.

\section{Crop insurance systems in $\mathbf{E U}$}

When we discuss insurance systems, we actually think of risks. In European countries, crops are most frequently insured against hail. There are countries such as Belgium, Great Britain, Ireland, Denmark and Finland in which crops can be insured solely against hail (Marković, Jovanović, 2008).

The so-called classic crop insurance types are applied in EU: insurance covering one risk, combined insurance and yield insurance. Insurance covering one risk is also called "Singleperil" or "Named-peril". It encompasses individual coverage and usually related to hail. Combined insurance (several risks) is called "Multiple-peril" (Labudović, Todorović, 2011). Profit insurance should also be mentioned as a form of agricultural protection that has existed in Great Britain for a very long time. This insurance covers risk of yield change and risk of product price change. However, it should be mentioned that risk of product price change falls in the so-called market risks that, as a rule, are noninsurable (Labudović, Todorović, 2011).

In addition to the insurance against hail, crops are frequently insured against other risks such as fire, frost, storms, etc. Insurance against drought, which is very problematic for farmers, very often does not fall in insured risks that we classify in combined insurance. Drought has a character of systemic risk because it can occupy a large territory and as a result there are a large number of claims for damages at the same time by a large number of insured. This is why it is not included in combined insurance, but it is in yield insurance (Labudović, Todorović, 2011). The countries in which this insurance system is present are former countries of the so-called "Eastern Bloc" that are now EU members. In those countries, namely, insurance used to be under government control and it was compulsory. When those countries adopted the market business system, including insurance, privatization occurred. Still, those insurance systems continue to develop. There are some differences in Poland though. 
Yield insurance is a special form of crop insurance. This insurance covers yield losses of specific crops resulting from the effects of foul weather. This insurance cannot be classified in multiple-peril insurance as it can be sometimes classified in combined insurance and sometimes we must apply it independently. The yield insurance system, which is present in several European countries such as Portugal, Austria, Luxembourg, Greece, Cyprus, France and Italy, damage must be evaluated that is a result of foul weather. When Spain is concerned, crop insurance against several risks includes loss of yield caused by the harmful event, or by the natural catastrophe. It is calculated when difference is determined between the guaranteed and effective yield. It is similar in USA and Canada (Labudović, Todorović, 2011).

Yield insurance of the whole husbandry covers loses of all crops in an agricultural husbandry. Lower yields of one crop will not be compensated by the insurer if lower production of the whole husbandry does not reach corresponding limiting value (Marković, Jovanović, 2008). Yield insurance covers losses caused in smaller yield due to bad weather. It is less represented due to high premiums. This form of protection exists in Austria, Luxembourg, France and Spain. Italy and Spain have a high risk of drought destroying pastures and rain during harvest falls in Austria, Italy and Poland. In Austria, this insurance is offered by specialized companies for mutual insurance. Unlike EU countries, in Canada and USA yield insurance is broadly represented. In USA, this insurance covers a large number of risks: drought, excess moisture, hail, wind, frost, insects and various diseases (Labudović, Todorović, 2011).

We would also like to mention here production value insurance that is a combination of yield insurance and price. In this case, compensation is paid if that production value does not reach the corresponding value. We also have profit insurance whose calculation includes production costs. Still, this system is more frequent in USA.

Insurance based on indices (indexed insurance) is based on details associated with a specific region or administrative unit (Labudović, Todorović, 2011). Indexed insurance as a basis takes the index brought into existence when measured by the authorized government agencies and not based on farmers' experience. The advantage of this insurance is that premiums and compensations for damages do not depend on individual experience by farmers and this is why there is no negative selection and moral hazard (Labudović, Todorović, 2011).

In the total structure of offers of crop insurance services, EU least accounts for yield insurance. All mentioned insurance types are offered by private insurers. The exceptions are Greece and Cyprus where there is a government program of crop and fruit insurance. Also, this insurance is compulsory in these countries (Labudović, Todorović, 2011). In Greece, otherwise, agricultural insurance is compulsory. The independent state organization ELGA provides various insurance types for crops against a large number of risks such as hail, frost, storms, floods, excess heat, excess downfalls and out-of-season downfalls, damages of bears and wild pigs, etc. (Agricultural Insurance). 
In most European countries full (complete) insurance is available solely for hail risk and in a limited range for frost and storm risks. When fruit insurance is concerned and it is very sensitive when speaking about frost risks, the insurance premium can reach 15 to $20 \%$ of the sum insured depending on the area where plantations are located, fruit types, possible franchises, etc. Agricultural producers can hardly afford such insurance. As a result of all this, many farmers in some parts of France have no insurance in this sphere (Rüegger).

One of the possibilities for overcoming this problem is risk transfer, or use of specific mechanisms that may provide protection on a broader scale. Many alternative concepts of risk management already exist and many depend on complex financial transactions and most include a considerable degree of self-funded losses. Such mechanisms are often cheaper than traditional insurance (Rüegger).

\section{Crop insurance in USA}

We have already mentioned several times some of the characteristics of crop insurance in USA that is well developed in this country. It is mainly combined insurance that covers several risks. Premiums are subsidized to a great extent and insurance is based on the evaluation of possible damages, weather forecast, etc. Compensation for damages is paid out if yield or profit fall below the guaranteed value (Agricultural Insurance).

Crop insurance program in USA includes traditional insurance against several risks and profit insurance. Premiums for profit insurance (and the sum insured) are determined based on expected profit and this is determined based on average profit in a specific period of time and also on the basis of market expectations (Dismukes at al., 2004).

\section{Subsidized insurance premium in EU countries}

In many EU member countries, farmers are allowed to have subsidized insurance premiums for the purpose of encouraging a more rapid development of this type of insurance. Practically, the state in this way allows risks to be reduced to a minimum (Manić, 2012). If we discuss government participation in insurance, or premium subsidy, one of more important conditions would be introduction of compulsory previous insurance conclusion by the agricultural producer so that the state could have an insight in the type of insurance and cover (Manić, 2012). State interventions are different when agricultural insurance is concerned. They can have the form of direct subsidies or indirect for expenses, loss and reinsurance. Many countries have provided subsidies to cover one part of the premium, whereas others have provided nearly all aspects of multiple perils associated for realizing risks like in USA and Canada (Smith, Glauber, 2012). When the agricultural insurance sector is under the influence of several state programs, one set of those policies could have effects on others. This is particularly important to emphasize for crop insurance (Smith, Glauber, 2012). When subsidized premiums by the state are concerned, the situation is different in EU member countries. We are giving some examples here. In 
Italy, percentage of subsidy is $64 \%$ of total premium and the same percentage is also for multiple perils insurance for yield insurance. In Spain, this percentage is $49 \%$ including regional subsidies. In Austria it is 46\% including regional subsidies and 50\% against frost and hail. In the Czech Republic it is 30\% for crop insurance. In Slovenia 30 to 50\% is given for basic risks. In Cyprus it is 50\% against all risks for compulsory insurance schemes (Bielza et al., 2009).

Denmark is a very important example of market penetration with yet $85 \%$ insured hectares of total cultivable land. For all payments by the state, over the level of insured amounts, Denmark conditioners its farmers with participation in the Fund for catastrophic damages which compensates for any damages in case of harmful events. In Bulgaria, which has a high level of market penetration, agricultural insurance is not compulsory, but one of the conditions to obtain subsidy in agriculture from the state is concluding of adequate insurance policy. In Poland, similarly to the Bulgarian model, farmers are also conditioned with insurance policies in order to use subsidy in agriculture from EU funds.

Apart from the fact that some EU countries do not condition subsidies in agriculture with agricultural production insurance policies, like in Austria and Sweden, the confirmation to the effect how developed awareness of insurers concerning necessity of agricultural insurance has an effect on the degree of market penetration are those two countries. In Austria, even $78 \%$ of total cultivable soil is insured and in Sweden this percentage is 60\% (Manić, 2012).

We must also mention Hungary, which is a good example for the influence that premium subsidy has on insurance development in agriculture. Since 2004, Hungary has discontinued earlier premium subsidies, many farmers have not insured their production and this resulted in an increase of total risks and a considerable fall of the insurers' profits. In accordance with this situation, Hungary has decided to take an active role again and develop an insurance agricultural model like in Spain. Many countries could use this model and it will be mentioned later on.

French and Italian agricultural insurance systems have been developed in the past four decades under the supervision of governments of those countries and inside the European joint agricultural politics. This was rather contributed by the Agriculture Agreement brought within the World Trade Organization that allowed development of this insurance system with the support of public insurance sector. This system was also helped by the experience of the countries of North America and South Europe (Spain, Italy and Greece). Also, agricultural politics of European countries have had to consider price instability and frequent exposure of farmers to natural catastrophes. (Enjolras et al., 2012).

In France, by 1964, there was no agricultural insurance program that was sponsored by the state. After a number of droughts, a National Guarantee Fund was founded for farmers affected by disasters and it was jointly funded by the budget and taxes levied on compulsory standard insured policies concluded by farmers (Enjolras et al., 2012). 
As far as state intervention in Italy is concerned in this sphere, "Fondo de Solidarfieta Nazionale in Agricoltora" has been functioning since 1974. Its aim is to provide funds to farmers so that they could effectively manage their production risks. This system has evolved over the years through various reforms until Italy has received guidelines from EU for giving state support in the agricultural sector (Enjolras et al., 2012).

In many countries there are no public private partnerships with government support allowing conclusion of agricultural insurance with private companies or producers' cooperatives. One of the leading programs in this sphere is associated with Spain. The Spanish model is a specially created model of public-private partnership (Manić, 2012). In 1980, Spanish government founded "Agroseguro" that consisted of private insurance companies and national reinsurance companies. "Agroseguro "specifies rates for various insurance products offered to agricultural producers with subsidized prices (Smith, Glauber, 2012). It is cooperation of the private and public sector through participation of the Ministry of Agriculture agency "Enese" and the above association of private insurance companies "Agroseguro" and the state company "CSS" (Concorsio de Compensacion de Seguros) that is under control of the Ministry of Economy with a task to provide reinsurance of excess risk in such insurance. When "Enese" is concerned, this agency brings an annual insurance plan in agriculture and then takes part in decision-making concerning the amount of premium subsidy and coordinates cooperation with farmers' associations, provides general insurance conditions and cooperates with the association of insurance companies regarding plans for insurance implementation. "Agroseguro" provides special conditions and insurance rates, performs control of sale channels, premium payment and damage handling. "CSS" has the role of the main reinsurance company, it is a participant in the fund and performs control of handled damages. The Spanish model is characteristic because the insurance companies manage risks with the help of the fund based on coinsurance. The fund is under control of "Agroseguro" and is reinsured by "CSS" (Manić, 2012).

In Spain, agricultural insurance policy is based on giving guidelines to autonomous regions that could specify their own needs in any specific case. The Spanish system is based on the following principles: - universal application aimed at covering as many risks as possible in as many regions as possible; - voluntary insurance; - insurance is the responsibility of any insured - farmer and insurance companies must not refuse to insure the "recognizable risk"; - full risk coverage (Agricultural Insurance).

\section{Crop insurance in Serbia}

We will briefly mention implementation of agricultural insurance in Serbia. There are two basic forms in this area: crop and fruit insurance and animal insurance. In crop and fruit insurance it covers loss of yield as a result of damages of agricultural cultures of insured risk. This coverage includes the following risks: hail, fire and thunder. We must say that this insurance emphasizes hail risk. This insurance can include storm, flooding and frost risks and insurance against loss of seed quality, loss of quantity and quality of fruit and table grapes, etc. 
In addition to the above risks, we must mention the risks that have been insured in recent times. Those are drought risks for particular agrarian cultures and risks of excess downfalls. Although these types of insurance of crops and fruit are still new here, it must be said in principle that this insurance type is gradually paid increasing attention (Manić, 2012).

\section{Conclusion}

It is hard to say which crop insurance model would suit the needs of agricultural producers. Selection of insurance models depends on many factors we could observe both from the state point of view and from the point of view of agricultural producers. We must consider average yield values, weather conditions and short-term and long-term weather forecast. If we discuss yield insurance of a specific region, then, as an insurance basis we must take into account the difference between earlier determined average yield for that region and the actually realized average yield. In such case, possible compensation would be paid independently of real damages on some rural estates. If we discuss insurance based on production value of a particular region, it is based on the product with average yield and price for the particular region. If this amount is lower than the previously determined average value of production for this region, compensation will be paid to all insured rural producers of this region. On the other hand, indirect indexed insurance does not relate to average yield of a particular region, but to adequate meteorological parameters. In this case, compensation is paid if the specified limiting value has been exceeded or has not been reached. The limiting value refers to the quantity of downfalls or average temperature (Marković, Jovanović, 2008).

Agricultural insurance is complex and requires high technological expertise in all operating phases, from risk evaluation, through insurance conclusion to damage calculation and its compensation. Private insurance markets have proved to be efficient in this sphere, but pure commercial insurance cannot be sustainable for systemic risks and small agricultural producers. The primary role of the state should be to develop insurance markets and eliminate regulatory shortcomings aimed at encouraging reinsurance, among other things (Mahul, Stutley, 2010).

The following must be defined when determining models of state support to agricultural insurance: 1 . foundation of an expertise centre that would be able to gradually increase the number of concluded insurance in this sphere; 2. foundation of a core for a team of agricultural insurance experts; 3 . creation of a central database with all elements relating to agricultural insurance and allowing availability of such base; 4. promotion and exchange of knowledge between insurance companies through organized training, issue of manuals, etc. (Mahul, Stutley, 2010).

\section{Literature}

1. Agricultural Insurance, available at: https://www.agriculture.gov.ie/media/migration/agrifoodindustry/foodharvest2020/ foodharvest2020/2020strategy/2020RiskIns.doc 
2. Bastian, C. (1999): Crop Insurance as a Tool, Risk and Resilience in Agriculture, University of Wyoming, Cooperative Extension Service, pp. 1-7, available at: www.uwagec.org/rnrinag/RnR $\% 20$ Section $\% 202 /$ Crop $\% 20$ Insurance $\% 20$ as $\% 20$ a\%20Tool.pdf

3. Bielza Diaz-Caneja, M., Conte, C. G., Gallego Pinilla, F. J., Stroblmair, J., Catenaro, R., Dittmann, C. (2009): Risk Management and Agricultural insurance Schemes in Europe, European Commission, Joint Research Centre, Institute for Protection and Security of Citizen, Luxembourg.

4. Čolović, V. (2013): Primena projekta „Solventnost II“ i mere koje su predviđene u Zakonu o osiguranju Srbije u slučaju neprimene pravila o upravljanju rizikom, Zbornik radova sa međunarodnog naučnog skupa „Osiguranje i naknada štete“, Zlatibor.

5. Dismukes, R., Bird, J., Linse, F. (2004): Risk Management Tools in Europe: Agricultural Insurance, Futures and Options, U.S.-EU Food and Agriculture Comparisons/WRS-04-04, Economic Research Service, USDA.

6. Enjolras, G., Capitanio, F., Adinolfi, F. (2012): The demand for crop insurance: Combined approaches for France and Italy, Agricultural Economics Review, Vol. 13, No. 1, pp. 5-22.

7. Ivanović, S. (2003): Upravljanje rizikom i osiguranje, časopis Industrija, Ekonomski institut, Beograd, vol. 31, br. 1-2, pp. 69-82.

8. Labudović Stanković, J., Todorović, N. (2011): Osiguranje biljne proizvodnje u EU i Srbiji, Ekonomika poljoprivrede, IEP Beograd, vol. 58, no. 4, pp. 723-734.

9. Mahul, O., Stutley, C. J. (2010): Government Support to Agricultural Insurance Challenges and Options for Developing Countries, the World Bank, Washington.

10.Manić, V. (2012): Osiguranje u poljoprivredi: Uloga javnog sektora, industrije osiguranja i pravci razvoja, Drugi poljoprivredni forum „Hrana za Evropu - u susret novoj strategiji razvoja agroprivrede Srbije“, Panel 4: Osiguranje u poljoprivredi: preduslov za sigurnije poslovanje, Subotica.

11.Marković, T., Jovanović, M. (2008): Postojeći sistemi osiguranja useva i plodova kao instrument za upravljanje rizikom u poljoprivredi, Agroekonomika, Poljoprivredni fakultet Novi Sad, br. 39-40, pp. 110-116.

12.Milikić, N. (2005): Upravljanje rizikom procene maksimalnog samopridržaja, specijalistički rad, Ekonomski fakultet Univerziteta u Beogradu, Beograd.

13. Rüegger, M., Trends in Agriculture Insurance in the European Union, Agriculture Reinsurance, Winterthur, Switzerland, available at: www.microinsurancecentre. org/resources/documents/doc download/330-trends-in-agricultural-insurance-inthe-european-union.html

14. Smith, V. H., Glauber, J. W. (2012): Agricultural Insurance in Developed Countries: Where Have We Been and Where Are We Going?, Applied Economic Perspectives and Policy, vol. 34, no. 3, pp. 363-390.

15.Smith, V. H., Watts, M. (2009): Index Based Agricultural Insurance in Developing 
Countries: Feasibility, Scalability and Sustainability, Monograph published electronically by the Bill and Melinda Gates Foundation, November 2009, available at: $\quad$ www.yumpu.com/en/document/view/16834278/index-based-agriculturalinsurance-in-developing-countries-

16. Šulejić, P. (2005): Pravo osiguranja, Misao, Beograd.

17.Žarković, N. (2008): Ekonomika osiguranja, Univerzitet Singidunum, Beograd.

\title{
OSIGURANJE USEVA - RIZICI I MODELI OSIGURANJA
}

\section{Vladimir Čolović ${ }^{3}$, Nataša Mrvić Petrović ${ }^{4}$}

\begin{abstract}
Rezime
Pitanje zaštite useva je veoma važno zbog različitih rizika koji mogu da izazovu teške posledice. Jedna vrsta zaštite od rizika je i osiguranje. Autor u radu navodi različite modele osiguranja u nekim zemljama EU, kao i sisteme subvencionisanja premije osiguranja od strane države. Takođe, autor daje sliku osiguranja useva i u SAD, navodeći da se u ovoj zemlji poklanja velika pažnja ovoj materiji. Što se tiče osiguranja u Srbiji, ono nije na zavidnom nivou. Osnovni problem kod osiguranja useva nije vezan samo za rizike, već i za način zaštite putem osiguranja. Osnovno pitanje koje se nameće ne samo u EU je ko će osigurati i zaštiti useve. Postoje tri mogućnosti: osiguravajuća društva koja su pod kontrolom države, društva koja predstavljaju javno-privatna partnerstva ili privatna društva na čisto tržišnim osnovama
\end{abstract}

Ključne reči: osiguranje, poljoprivreda, usevi, premija, rizik.

3 Prof. dr Vladimir Čolović, redovni profesor, naučni savetnik, Institut za uporedno pravo, Terazije 41, 11000 Beograd, Telefon: +381 11323 32 13, E-mail: vlad966@hotmail.com

4 Prof. dr Nataša Mrvić-Petrović, redovni profesor, naučni savetnik, Institut za uporedno pravo, Terazije 41, 11000 Beograd, Telefon: +381 11323 32 13, E-mail: petroviczdravko@ikomline.net 